\title{
Impact of Covid-19 on Hotel Industry: A System Approach
}

\author{
Faize Ali Shah, Research Scholar, Faculty of Social Sciences, Dayalbagh Educational Institute, \\ Dayalbagh, Agra, India, faizeshahdei@gmail.com \\ Vanshika Tandon, Student, Symbiosis Centre for Distance Learning, Pune, India, \\ vanshika.tandon101@gmail.com
}

\begin{abstract}
When nature is at its discourse, seldom can a habitat and its species protect themselves from its hazardous consequences. This can be evidently justified by the recent pronouncement of PHEIC (Public Health Emergency of International Concern) by the WHO in December $2019^{[1]}$ symbolizing the potential threats of novel corona virus and its ability to impact lives all across the globe. Unambiguously, if lives are obstructed, the economies of countries around the world also tend to become lopsided thereby causing a state of alarm ${ }^{[2]}$. Consequently, India is also not sheltered from the calamitous impact of COVID- 19. Being a developing country, it has become extremely problematic to tackle this massive healthcare emergency coupled with low permeability, uneven systems of commercial sectors and logistical unfeasibility to implicate a successful mass quarantine ${ }^{[3]}$ leading to a disturbed impact on all commercial sectors of the society through an ever decreasing GDP rate encompassing various restrictions imposed by the government on hospitality, tourism and aviation ${ }^{[1]}$ including the hotel industry. This paper primarily focuses on the impact of the novel coronavirus epidemic on Indian hotels through analysis of three primary factors encompassing tourism, consumer satisfaction and employee satisfaction and its possible aftermath through investigation of the factors linked to this industry and crucially affecting its functioning with the aid of a system approach.
\end{abstract}

Keywords - COVID-19, consumer, employee, hotel industry, system dynamics.

\section{INTRODUCTION}

Hotels are complex organizations that are synchronized by the aid of investors, bricks and mortar and aim at creating value for customers ${ }^{[4]}$. The hospitality industry is bound to the society till such an extent that even the tiniest transformation in these factors inculcates major metamorphoses in its cyclic functioning. There are many such determinants that call for in-depth study so that efficacious steps can be taken to ensure proper operations during the time of pandemics. The researcher has investigated those factors that are an inseparable part of the hotel industry and how COVID-19 has impacted its operative activities in positive or negative ways. Due to an unprecedented scope and duration of this novel disease, the hotel industry is in extreme crises ${ }^{[5]}$. As per the report issued by a leading hotel website ${ }^{[6]}$, occupancy in hotels after the international health emergency has reduced from an enormous margin of 45 percentage points from the year 2019 imposing the toughest times in front of the Indian hospitality sector and revoking from this loss might also take a great deal of time, efficient use of resources and local societal aid.
For preliminary investigation of the various elements of the hotel industry that have been adversely affected by COVID-19, the researcher categorized three distinct factors that can be regarded as the most vital foundational elements of smooth functioning of hotels. In order to profoundly analyze these factors, system approach was the most appropriate option as it not only looks at a problem but presents a complete picture so that conceptual and methodical ${ }^{[7]}$ scrutiny might aid in minimizing disastrous impacts of a crisis. It provides relationship patterns existing between the factors and sub-factors associated with them.

\section{Tourism}

As suggested by a recent study ${ }^{[8]}$, there is a negative relationship between any epidemic and tendency of people to opt for tourism and staying at hotels thus encouraging social distancing in order to ensure complete safety for themselves as well as their loved ones ${ }^{[9]}$ thereby making tourism the foremost factor affected due to the spread of coronavirus.. However, the travel restrictions imposed by governments of those countries which are regarded as epicenters of virus spread also contribute in lack of 
prospective tourism as well ${ }^{[10]}$.

Within an adequate market environment, tourism promotes successful running of hotels ensuring mass occupancy as well as event reservations. But the tendency of such a large scale crisis to potentially increase in size as well as frequency due to hypermobility, promotes haphazardness as time passes ${ }^{[11]}$. As initiated by some eminent researchers ${ }^{[12]}$, tourism industry is not less than a backbone for effective functioning of any hotel or resort and thus, pandemics create hurdles in their operations due to the unsteady pace of the market environment which otherwise promotes it by providing expansion opportunities and access to resources. Such disruption in the environment can be associated with difficulties financial accountability of stakeholders and investors towards the government ${ }^{[13]}$ and prospective guests alike. This is basically due to the worst case consequences of almost zero returns and gigantic toil of handling fixed costs. Moreover, as per some analysts, ${ }^{[14]}$ financial crisis in a country contributes to a disturbed monetary soundness in the hotel industry. As tourism and relaxation is becoming a necessity, unwanted economic crisis affects the common man's pocket and disrupts the hotel industry ${ }^{[15]}$. Resultantly, it has been stated that scrutiny and analysis of the economic impacts of lack of tourism in a country might aid in minimizing its after effects on the service sector ${ }^{[16]}$. Therefore, analysts ${ }^{[17]}$ have also specified the vital investigation of the relationship between tourism and crisis management especially during pandemics as this might aid hoteliers to channelize their limited resources of man and material accordingly.

\section{Customer Satisfaction}

Most of the prospective guests or travellers desirous of hotel stay, be it international or regional, are desirous of stress free experiences at all times and even aim for a host of complementary advantages associated with their stay. Hence, when restrictions are imposed for their prearranged stopovers ${ }^{[18]}$ especially when their leisure time as well as health, are at risk, the mammoth task of reassurance and credibility comes on maintaining their satisfaction levels. Thereby customer satisfaction is one of the most tested factors in these times. Often, consumers tend to shun travelling or going to public places as they find it risky due to the probability of getting infected ${ }^{[19]}$. In a similar context, some ${ }^{[20]}$ have investigated evolutionary motives of buying behavior among consumers, evading physical or mental harm being one of them. As a result, an analyst ${ }^{[21]}$ has concentrated upon the tendency of passengers to indulge in cancellations especially during such uncertainties and those conditions which modify cancellation policies which often link to similar cancellations of event bookings and other room acquisitions fixated with demands for refunds as consumer spending on accommodation in hotels is associated with the prevalent conditions of a working economy ${ }^{[22]}$. Additionally, price issues among consumers have been static in the field of customer satisfaction but when a global emergency takes over, these concerns become ${ }^{[23]}$ resulting in an adverse aggregate demand shock in the hotel industry ${ }^{[24]}$.

As validated further, restrictions imposed by the government critically hinder the liberated functioning of an organization and create an impact on its image ${ }^{[25]}$. Although, government mitigation becomes obligatory ${ }^{[26]}$ to rescue from grave losses and lopsided reputation of such businesses and thus aiding in tackling the situation by providing required equipment and thorough scanning of the hotel premises ${ }^{[27]}$. This in turn uplifts the reputation of the hotel and its tendency to value the safety of its staff and guests at the top notch. With tasks to perform at such a large scale, hotel industry tends to transform into not less than a rapid action force in itself and provoking the currently staying guests to do the same, through immediate quarantine and safe distancing for ensuring prevention of mass spread ${ }^{[28]}$ thus inviting exhaustive work load on both ends.

\section{Employee Satisfaction}

Further intensifying the impact of COVID-19 on employees of the hotel industry, such critical situations test the patience of employees as well hence the researcher has also scrutinized employee satisfaction by digging into those aspects of an employee's work life that are pressurized the most ${ }^{[29]}$ and the extent to which his job is able to provide him marginal satisfaction. Intensifying this, if his relationship with superiors or subordinates is strained, his satisfaction levels tend to reduce considerably ${ }^{[30]}$. On top of this, as per an article ${ }^{[31]}$, Indian hotel industry is bound to face incredible losses amounting to no less than 1.5 billion dollars owing to cancellations of weddings, conferences and hotel room bookings thereby hindering sources of income, recovery rate being considerably low thus prompting towards job insecurities. It is noteworthy to say that due to contractual restrictions and opportunistic behavior, revenue earning in hotels is not predictable in such adverse circumstances ${ }^{[32]}$ thereby contributing to a dearth in profitable revenue earning and growth even in days of high demands of leisure time or opting for corporate or social gatherings leading to a termination of such activities. Moreover, in the extreme and stiff competitive turf of the hotel industry, revenue management ${ }^{[33]}$ is bound to be challenging specifically due to inadequacy even in peak times on which most of the inns and local resorts depend for revenue generation thereby targeting operational efficiency of the hotel industry. Though it should not be forgone that challenging customers in recent times, effectiveness of operations in hotels has enhanced ${ }^{[34]}$ which has been tested recently amidst the spread of coronavirus. During such bad times, one thing that managers ought to perform is boosting efficiency which can be done by ensuring propensity of 
employees ${ }^{[35]}$ as they too are shaken from the unknown.

Additionally, chunk of the hotels with massive amount of luxurious facilities rely on high occupancy rates and events and such pandemics cause extensive damage and it might become difficult for hoteliers to sustain both lavish and subtle properties without incurring losses ${ }^{[36]}$ thereby cost control being the only way out. In a similar fashion, it has been presented that working conditions of employees determine their loyalty towards an industry ${ }^{[37]}$ and in such a risky situation which involves dire consequences, working conditions need to be superior enough so that an employee can be reinstated effectively involving apt sanitization and all measures of remaining contact less while on duty. However, employee turnover is impacted and it is not apt to believe that only superior working conditions can hold employees in the hotel, these health emergencies also affect their performance and make their retention ${ }^{[38]}$ an issue of concern.

\section{OBJECTIVES}

For appropriate investigation, an analysis is dependent on pre-set objectives that define the structural framework of the focal purpose of a precise study. They direct the pathway for effective scrutiny conducted by a researcher ${ }^{[39]}$. The present research paper investigates those factors associated with the hotel industry that are affected unfavorably due to COVID-19 and as a result of which; the hotel industry is altogether adversely misbalanced. The objective of this study is to determine the factors affected by COVID-19 and its impact on hotel industry. These factors are scrutinized to be the most impactful on the functioning of the hotel industry during the global health emergency of COVID-19. This study is restricted to Agra city, the sample units being managers of five star and three star hotels of Agra.

\section{SCOPE OF STUDY}

For an effective exploration, the researcher found at to select a sample so that systematic analysis can be conducted ${ }^{[40]}$. There are many sampling techniques associated with qualitative researches however the researcher has opted for judgmental and convenience sampling. During these though times, the functioning of both five star and three star hotels was hampered the most due to their large scale fixed costs and nerve-wrecking liabilities resultant of disruptive bookings and cancelations. So, it was found apt to select these hotels as these could provide a vivid information regarding their operations which could not be obtained from other sources by being an indispensable part ${ }^{[41]}$ of the hotel industry. For filling up self-structured questionnaires that would aid in determination of prominently impacted factors, convenience sampling was undertaken as it aims at those respondents that happen to be available and willingly contributing their time and energy for such investigations ${ }^{[42]}$. Here, 100 such managers of five star and three star hotels positioned in the city of Agra, were approached as they have a detailed inkling of the prevailing situation and its causative elements.

\section{IMPROVEMENT IN PERFORMANCE} ANALYSIS

As per the system module, three primary factors that determine the functioning of hotel industry and are impacted by the initiation of corona virus on a global scale. These factors comprised of tourism, customer satisfaction and employee satisfaction. Tourism has been the most impacted and that too severely due to restrictions imposed by several governments on travelling, thus arising economic crisis within a country not foregoing fluctuations in the market environment. Furthermore, if the market is disrupted, light is shed upon financial accountability of respective hotels. Customer satisfaction too is found to possess a direct link with the prevailing market conditions which in turn define pricing policies of hotels. Ultimately, pricing schemes depend on the extent of regulations imposed by the government which impact the overall image of the hotel, thus contributing in degrading or uplifting customer satisfaction levels.

When it comes to employee satisfaction, it turned out to be adversely affected due to work load which in turn connects with the economic crisis currently prevailing. Moreover, constant lack of revenue also affected the operational efficiency of the hotels as well as led to cost control thereby ensuring a circular loop. For controlling expenditures, working conditions were not found to be appropriate as per the need of the hour which in turn impacted the turnover of employees in a negative manner. Eventually, this employee turnover was found to be linked to the prevailing market conditions which are extremely intense and cut-throat.

\section{RESEARCH METHODOLOGY}

This section elucidates the methodology of research opted for the determination of factors of the hotel industry impacted by COVID- 19, based on system approach ${ }^{[43]}$. Three prominent factors were brought into limelight encompassing tourism, customer satisfaction and employee satisfaction not foregoing associated sub-factors linked to each of them. As the sample size is 100 managers of five star and three star hotels of Agra, the data was primarily collected through self-structured questionnaires that were requested to be filled by 100 hotel managers so that a vivid idea of their perceptions in recent times can be taken and further interpreted qualitatively.

The figure given below gives a critical picture of the havoc caused by COVID-19 on the hotel industry. As depicted, tourism, customer satisfaction and employee satisfaction are the most severely affected ones. As 
represented, the researcher has also formulated certain sub factors as brought about through the data collected by selfstructured questionnaires. Tourism is bound to get affected by economic crisis and this in turn raises the efforts required for a sound and apt financial accountability of the hotel. Moreover, customer satisfaction is linked to the pricing policies of the hotels as well as hotel image is put to test in such times. Finally, employee satisfaction gets greatly impacted by the working conditions which in turn affect their turnover. Some other sub factors have also been represented in the figure.

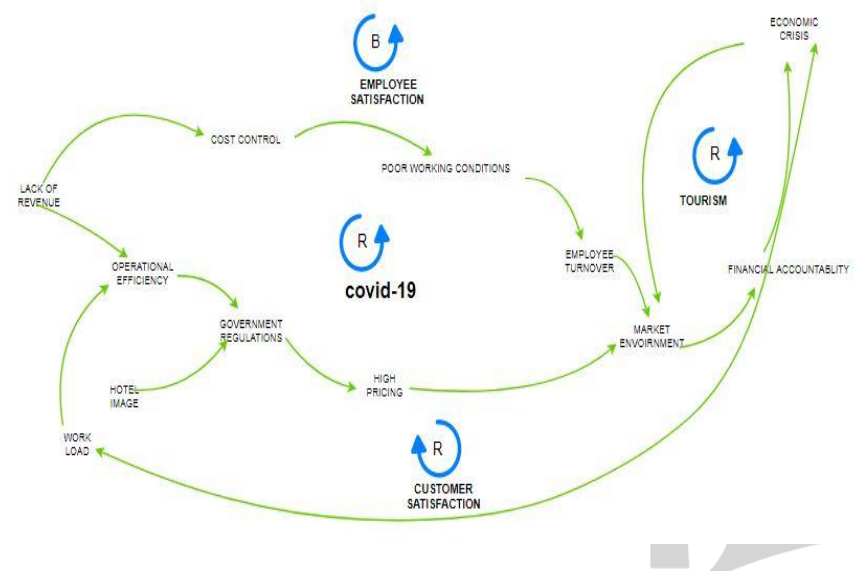

Fig. 1

\section{CONCLUSION AND SUGGESTIONS}

With folks self-isolating ${ }^{[44]}$ it is becoming exceptionally challenging for hoteliers. Furthermore, according to a report ${ }^{[45]}$, the outbreak has tremendously changed their mentalities and sentiments, lifestyles as well as social and entertainment activities. In turn, this has nurtured irreplaceable losses for the hotel industry, the revenue of which is completely dependent on their guests and accomplishments of their demands through quality and best possible means. This study highlights most essential factors of tourism, customer satisfaction and employee satisfaction and their associated sub-factors affected due to the global scale health emergency of COVID-19.

Tourism was found to be co-dependent on the economic crisis of a country as well as enhanced aims of financial accountability. Furthermore, customer satisfaction in such unprecedented times is found to be related to mostly hotel image as changes in pricing and refund policies. Ultimately, employee satisfaction paralleled with impact on operational efficiency, work load and their working conditions. These major findings would aid analysts and research enthusiasts to formulate present and future policies accordingly. This, in turn might educate manpower of tourism and hospitality industry for all sorts of emergencies that might propel in the near future so that the impairment caused is bare minimum [46]

\section{REFERENCES}

[1] Dr. Amit Kumar, "Disastrous impact of Coronavirus (COVID 19) on Tourism and Hospitality Industry in India," Journal of Xi'an University of Architecture \& Technology, vol. XII, no. V, pp. 698- 712, 2020.

[2] Marlya Maliszewska, Aaditya Mattoo, Dominique Van Der Mensbrugghe, "The potential impact of COVID-19 on GDP and trade: A preliminary assessment," World Bank e-library, 2020.

[3] Dr. Arun Gaikwad, CMA Satish Dhokare, "Coronavirus: The Impact of Covid-19 on India Economy," Purakala, vol. 31, no. 33, pp. 242-253, May 2020.

[4] Simon Oaten, Katherine Le Quesne, Harry Segal and Deloitte LLP, "Adapting to Uncertainty - The Global Hotel Industry," The Travel \& Tourism Competitiveness Report, pp. 47-51, 2015.

[5] Adel Ben Youssef, Adelina Zeqiri and But Dedaj, "Short and Long Run Effects of COVID-19 on the Hospitality Industry and the Potential Effects on Jet Fuel Markets," International Association for Energy Economics Energy Forum / Covid-19 Issue, pp. 121-124, 2020.

[6] BW Online Bureau, "COVID-19: Impact on the Indian Hotels Sector,A Report by HVS," BW Hotelier.com, 2020.

[7] Chen Gordon K. C, "What is the Systems Approach?" Interfaces, vol. 6, no. 1, November 1975.

[8] Wasiul Karim, Ahasanul Haque, Zohurul Anis and Mohammad Arije Ulfy, "The Movement Control Order (MCO) for COVID-19 Crisis and its Impact on Tourism and Hospitality Sector in Malaysia," International Tourism and Hospitality Journal, vol. 3, no. 2, pp. 1-7, January 2020.

[9] Ozili Peterson and Arun Thankom, "Spillover of COVID-19: Impact on the Global Economy," Munich Personal RePEc Archive, Paper No. 99850, April 2020.

[10] Matteo Chinazzi, Jessica T. Davis, Marco Ajelli, Corrado Gioannini, Maria Litvinova, Stefano Merler, Ana Pastore y Piontti, Kunpeng Mu, Luca Rossi, Kaiyuan Sun, Cécile Viboud, Xinyue Xiong, Hongjie Yu, M. Elizabeth Halloran, Ira M. Longini Jr. and Alessandro Vespignani, "The effect of travel restrictions on the spread of the 2019 novel coronavirus (COVID-19) outbreak," Science (Research Articles) vol. 368, pp. 395-400, 2020

[11] Hall Michael C, "Crisis events in tourism: subjects of crisis in tourism", Current Issues in Tourism, vol. 13, no. 5, pp. 401417,2010 .

[12] Ruwan Ranasinghe, Anupama Damunupola, Shamila Wijesundara, Chandi Karunarathna, Dhananjaya Nawarathna, Sammani Gamage, Amaya Ranaweera, Ali Abdulla Idroos, "Tourism after Corona: Impacts of COVID 19 Pandemic and Way Forward for Tourism, Hotel and Mice Industry in Sri Lanka," Department of Tourism Studies, Faculty of Management, Uva Wellassa University, 2020.

[13] Tazim Jamal and Christine Budke, "Tourism in a world with pandemics: local-global responsibility and action," Journal of Tourism Futures (Emerald), February 2020.

[14] Haiyan Song and Xinyan Zhang, "Impact of financial/economic crisis on demand for hotel rooms in Hong Kong," Tourism Management Journal (ELSEVIER), vol. 32, no. 1 pp. 172-186, February 2011.

[15] Klaus Dissertori, “Tourism providers' reactions to decreased demand following a crisis," Modul University, 2017. 
[16] Stephen Page, Haiyan Song, and Doris Chenguang Wu, "Assessing the Impacts of the Global Economic Crisis and Swine Flu on Inbound Tourism Demand in the United Kingdom," Journal of Travel Research (Sage Publications), vol. 51, no. 2, pp. 142-153.

[17] Hsiao-I Kuo, Chi-Chung Chen, Wei-Chun Tseng, Lan-Fen $\mathrm{Ju}$ and Bing-Wen Huang, "Assessing impacts of SARS and Avian Flu on international tourism demand in Asia," Tourism Management Journal (ELSEVIER), vol. 29, pp. 917-928, 2008

[18] The WHO, "Coronavirus disease 2019 (COVID-19) Situation Report - 57," WHO Official, March 2020.

[19] Hojin Jung, Minjae Park, Kihoon Hong and Eunjung Hyun, "The impact of an Epidemic Outbreak on Consumer Expenditures: An Empirical Assessment for MERS Korea," Sustainability Journal, vol. 8, no. 454, May 2016.

[20] Vladas Griskevicius and Douglas T. Kenrick, "Fundamental motives: How evolutionary needs influence consumer behavior," Journal of Consumer Psychology (ELSEVIER), vol. 23, no. 3, pp. 372-386, July 2013.

[21] ChihChien Chen, "Cancellation policies in the hotel, airline and restaurant industries," Journal of Revenue and Pricing Management, vol. 15, pp. 270-275, March 2016.

[22] Simon Oaten, Katherine Le Quesne and Harry Segal, "Adapting to Uncertainty- The Global Hotel Industry," Travel and Tourism Competitiveness Report, pp. 47-51, 2015.

[23] Cabral Luis and Xu Lei, "Seller Reputation and Price Gouging: Evidence from the COVID-19 Pandemic," 2020.

[24] Tsutomu Wantanabe, "The responses of consumption and prices in Japan to the COVID-19 crisis and the Tohoku Earthquake," Center on Japanese Economy and Business (Columbia Academic Commons), 2020.

[25] Karima R. Nigmatulina and Richard C. Larson, "Living with influenza: Impact of government imposed and voluntarily selected interventions," European Journal of Operational Research (ELSEVIER), vol. 195, no. 2, pp. 613-627, June 2009.

[26] Lawrence O. Gostin, "Inflenza A(H1N1) and Pandemic Preparedness Under the Rule of International Law," JAMA, 2009.

[27] Gregory P Campbell, "Global H1N1 Pandemic, Quarantine Law, and the DUE Process Conflict," San Diego Int'l LJ, vol. 12 , no. $497,2010$.

[28] Kevin K C. Hung, Carman K. M. Mark, May P. S. Yeung, Emily Y. Y. Chan and Colin A. Graham, "The role of the hotel industry in the response to emerging epidemics: a case study of SARS in 2003 and H1N1 swine flu in 2009 in Hong Kong," Globalization and Health, vol. 14, no. 117, 2018.

[29] Wireko-Gyebi Sampson and Ohenaba Akyeampong, "Wrokrelated Stress in Hotels: An Analysis of the Causes and Effects among Frontline Hotel Employees in the Kumasi Metropolis, Ghana," Journal of Tourism and Hospitality, vol. 3, no. 2, 2014.

[30] John W. O' Neill and Kelly Davis, "Work Stress and Wellbeing in the Hotel Industry," National Institute of Health, vol. 30, no. 2, pp. 385-390, June 2011.

[31] Achin Khanna, "Indian hotel industry could face losses of up to 1.5 billion, says Hotelivate report," Hospitality World.com, March 2020.
[32] Xuan Lorna Wang, "The impact of revenue management on hotel key account relationship development," International Journal of Contemporary Hospitality Management, vol. 24, no. 3, pp. 358-380, April 2012.

[33] Tatiana Pitubaeva, "The Effect of Holidays on Revenue of Hotels in South Karelia Region of Finland within the Context its Significant Impact on Revenue Management," Saimaa University of Applied Sciences, 2014.

[34] Chikwe Agaptus C., "The Impact of Employee Turnover: The Case of Leisure, Tourism and Hospitality Industry," Consortium Journal of Hospitality and Tourism, vol. 14, no. 1, pp. 43-56, 2009.

[35] Jui-Kou Shang, Fei-Ching Wang and Wei-Ting Hung, "A stochastic DEA study of hotel efficiency," Applied Economics Journal, vol. 42, no. 19, April 2009.

[36] Hai Wen, Zhong Zhao, Jian Wang and Zhen-Gang Hou, "The Short-Term Impact of SARS on the Chinese Economy," Asian Economic Papers, vol. 3, no. 1, 2003.

[37] Aiko Kuipers, "The effects of casualization on the working conditions of temporary employees in the hospitality industry," University of Johannesburg, 2014.

[38] Mark A. Bonn and Louis R. Forbringer, "Reducing turnover in the hospitality industry: an overview of recruitment, selection and retention," International Journal of Hospitality Management, vol. 11, no. 1, pp. 47-63, 1992.

[39] Pam Denicolo and Lucinda Becker, Developing Research Proposals, 2012.

[40] Taherdoost Hamed, "Sampling Methods in Research Methodology; How to Choose a Sampling Technique for Research", SSRN Electronic Journal, vol. 5, no. 2, pp. 18-27, January 2016.

[41] Westfall Linda, The Certified Quality Engineer Handbook, 2009.

[42] Onwuegbuzie Anthony $\mathrm{J}$ and Leech Nancy L, A call for qualitative power analyses, Quality and Quantity Journal, vol. 41, no. 1, pp. 105-121, 2007.

[43] Jackson Scott, Hitchins Derek and Eisner Howard, "What is the Systems Approach?", INSIGHT, April 2010.

[44] S. Mahendra Dev and Rajeswari Sengupta, "Covid-19: Impact on the Indian Economy," Indira Gandhi Institute of Development Research, April 2020.

[45] The Neilson Company, "Impact of COVID-19 on Consumer Behavior," 2020.

[46] Mohinder Chand, "Building and Educating Tomorrow's Manpower for Tourism and Hospitality Industry," International Journal of Hospitality \& Tourism Systems, vol. 9, no. 1, June 2016. 